Pontifícia U Universidade Católica $_{\text {Do Rio DE Janelro }}$

J honatan Gerardo Soto Puelles

Hematite flotation using a crude
biosurfactant extracted
Rhodococcus opacus

Dissertação de Mestrado

Dissertation presented to the Programa de Pós-graduação em Engenharia de Materiais e Processos Químicos e Metalúrgicos, PUC-Rio as partial fulfilment of the requirements for the degree of Mestre em Engenharia de Materiais e Processos Químicos e Metalúrgicos.

Advisor: Prof. Mauricio Leonardo Torem

Co-advisor: Dr. Antonio Gutiérrez Merma

Rio de Janeiro July 2016 
J honatan Gerardo Soto Puelles

\section{Hematite flotation using a crude biosurfactant extracted from Rhodococcus opacus}

Dissertation presented to the Programa de Pós-graduação em Engenharia de Materiais e Processos Químicos e Metalúrgicos, PUC-Rio as partial fulfilment of the requirements for the degree of Mestre em Engenharia de Materiais e Processos Químicos e Metalúrgicos.

Prof. Maurício Leonardo Torem

Advisor

Departamento de Engenharia Química e de Materiais -PUC-Rio

Dr. Antonio Gutiérrez Merma

Co-advisor

Departamento de Engenharia Química e de Materiais -PUC-Rio

Prof. Luís Alberto Cesar Teixeira Departamento de Engenharia Química e de Materiais -PUC-Rio

Dra. Flávia Paulucci Cianga Silvas Instituto Tecnológico Vale

Prof. Márcio da Silveira Carvalho

Coordinator of the Centro Técnico Científico da PUC-Rio

Rio de Janeiro, July $1^{\text {st }}, 2016$ 
All rights reserved

\section{J honatan Gerardo Soto Puelles}

Jhonatan Gerardo Soto Puelles holds a BSc. in Chemical Engineering from Universidad Nacional San Antonio Abad del Cusco (2012), and now a MSc. in Materials Engineering and Chemical and Metallurgical Processes from Pontifícia Universidade Católica do Rio de Janeiro. From 2012 to 2013, he studied software development. In 2013 he won an internship for 1 year in the Process Engineering Department in Petroperu S.A. From 2014 to 2016, he joined to the research group of Mineral Flotation and Biotechnology-PUC.

Bibliographic data

Soto Puelles, Jhonatan Gerardo

Hematite flotation using a crude biosurfactant extracted from Rhodococcus opacus / Jhonatan Gerardo Soto Puelles ; advisor: Mauricio Leonardo Torem ; co-advisor: Antonio Gutiérrez Merma. - 2016.

110 f. : il. color. ; $30 \mathrm{~cm}$

Dissertação (mestrado)-Pontifícia Universidade Católica do Rio de Janeiro, Departamento de Engenharia Química e de Materiais, 2016.

Inclui bibliografia

1. Engenharia Química - Teses. 2. Engenharia de materiais - Teses. 3. Hematita. 4. Bioflotação. 5. Rhodococcus opacus. 6. Biosurfactante. I. Torem, Mauricio Leonardo. II. Gutiérrez Merma, Antonio. III. Pontifícia Universidade Católica do Rio de Janeiro. Departamento de Engenharia Química e de Materiais. IV. Título. 


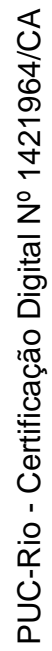

To my parents Lourdes and Renato for their continuous support and faith. Thanks 


\section{Acknowledgments}

Thank you God, for allow me fulfill my goals and support me in every complicated moment.

My gratitude to my advisor Prof. Mauricio L. Torem, for show me this amazing and always surprising world of the surface chemistry.

To Antonio, my co-advisor, for teaching me that two heads can think much better than one.

To Karen for help me get here and to all my friends for the good moments we lived and for their support.

To the professors Bernardo Diaz Ribeiro and Maria Alice Zarur Coelho from the Universidade Federal do Rio de Janeiro, for their advices and constructive observations.

To Gisllane Oliveira from the Laboratório de Caracterização de Fluidos (LCF) do Departamento de Engenharia Mecânica da PUC-Rio, for help me with the surface tension measurements.

I would also like to acknowledge the Coordenação de Aperfecionamento de Pessoal de Nível Superior (CAPES), Fundação de Amparo à Pesquisa do Estado do Rio de Janeiro (FAPERJ) and the Institute of Technology VALE for their financial support.

Finally, to the Department of Chemical and Materials Engineering, DEQM, and the Mineral Technology group, where it was developed this research. 


\section{Abstract}

Puelles, Jhonatan Gerardo Soto; Torem, Mauricio Leonardo (Advisor); Merma, Antonio Gutiérrez (Co-advisor). Hematite flotation using a crude biosurfactant extracted from Rhodococcus opacus. Rio de Janeiro, 2016. 110p. MSc. Dissertation -Departamento de Engenharia Química e de Materiais, Pontifícia Universidade Católica do Rio de Janeiro.

Bioflotation is defined as a separation process by which the mineral of interest is floated or depressed selectively, using reagents of biologic origin also known as bioreagents. These substances are characterized by their green chemistry, selectivity and potential to treat fine particles. Currently they are been studied with the expectative of substitute the synthetic reagents used in the mineral flotation processes. Between the diverse microorganisms, the hydrophobic bacteria Rhodococcus opacus has been studied as biofrother and biocollector in hematite flotation. In that sense, the research's principal objective is the assessment of the hematite floatability using a crude biosurfactant extracted from the bacteria Rhodococcus opacus and consequently determine its potential as an alternative against synthetic reagents or the bacteria itself. In a first stage, it was developed a protocol for the extraction of cell associated and intracellular biosurfactants from the bacteria. Throughout ethanol extraction at $121^{\circ} \mathrm{C}$ and $2 \mathrm{~atm}$, the cell associated substances where released and solubilized. The average crude biosurfactant recovery was around $0.3 \mathrm{~g}$ per L of broth. Characterization by FTIR identified alcohol $(-\mathrm{OH})$ and ketone $(\mathrm{C}=\mathrm{O})$ groups as well as saturated and unsaturated carbon chains. Which may compose the mycolates and trehalolopids that are found in the cellular wall of the genera Rhodococci. Electrophoretic studies of the hematite sample, before BS interaction, found an IEP around a $\mathrm{pH}$ of 7.5 and a PZC at $\mathrm{pH}$ 7.6. Applying the Guoy-Chapman model and the mixed model of Guoy Chapman and the plate capacitor, it was possible to study the effect of the biosurfactant onto the electrostatic behavior of the hematite particles. The model predicted the hydrophobicity of the modified hematite at acid $\mathrm{pH}$. Finally it was tested the crude biosurfactant against the bacteria itself in microflotation tests, resulting the first one 
in an improved hematite floatability. The results showed a high affinity of the crude biosurfactant for hematite particles and relatively low reagent consumption.

\section{Keywords}

Hematite; bioflotation; Rhodococcus opacus; biosurfactant. 


\section{Resumo}

Puelles, Jhonatan Gerardo Soto; Torem, Mauricio Leonardo; Merma, Antonio Gutiérrez. Flotação de hematita usando um biosurfactante não refinado extraído da Rhodococcus opacus. Rio de Janeiro, 2016. 110p. Dissertação de Mestrado -Departamento de Engenharia Química e de Materiais, Pontifícia Universidade Católica do Rio de Janeiro.

A bioflotação é definida como um processo de separação, através do qual o mineral de interesse é flotado ou deprimido seletivamente, utilizando os reagentes de origem biológica, também conhecidos como bioreagentes. Estas substâncias são caracterizadas por possuírem uma química verde, seletividade e potencial para tratar a partículas finas. Neste sentido, o objetivo principal da pesquisa é a avaliação de um biosurfactante não refinado extraído da bactéria Rhodococcus opacus na flotação de hematita. Na primeira fase, foi desenvolvido um protocolo para a extração dos biosurfactantes intracelulares e aqueles associados a parede celular da bactéria. Mediante extração com etanol a $121^{\circ} \mathrm{C}$ e 2 atm, as substâncias anfifílicas foram liberadas e solubilizadas. A recuperação média de biosurfactante não refinado foi de $0,3 \mathrm{~g}$ por $\mathrm{dm}^{3}$. A caracterização por FTIR identificou grupos álcool $(-\mathrm{OH})$, cetona $(\mathrm{C}=\mathrm{O})$ e cadeias de carbono saturadas e insaturadas. Que podem compor os mycolatas e trehalolipideos que são encontrados na parede celular da bacteria. Por estudos eletroforéticos encontrou-se um PIE de 7,5 e um PZC em torno de 7,6. Aplicando o modelo Gouy-Chapman e o modelo misto de Gouy Chapman e o capacitor de placas, foi possível estudar o efeito do biosurfactante no comportamento eletrostático das partículas de hematita. Predizendo como elas foram se tornando hidrofóbicas em valores de $\mathrm{pH}$ ácido e como sua flotabilidade diminuía em pH básicos, após interação com o biosurfactante. Finalmente, foi testado o biosurfactante e a própria bactéria em ensaios de microflotação de hematita, resultando o primeiro na melhora na flotabilidade de hematita. Os resultados mostraram uma boa afinidade e baixo consumo de reagente.

\section{Palavras-chave}

Hematita; bioflotação; Rhodococcus opacus; biosurfactante. 


\section{Contents}

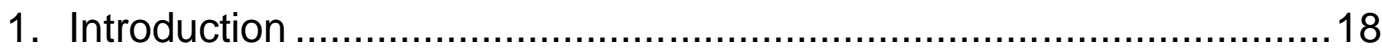

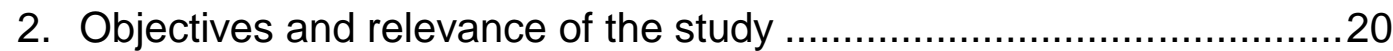

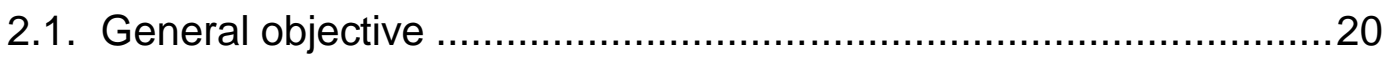

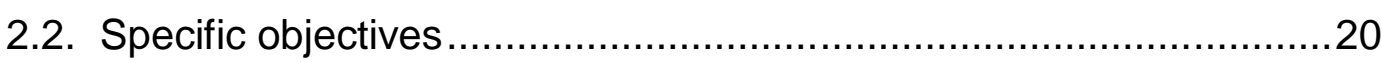

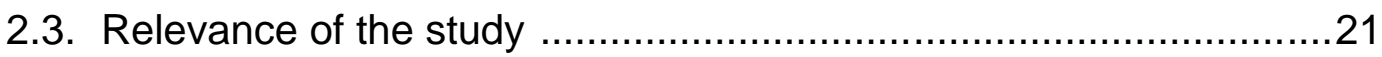

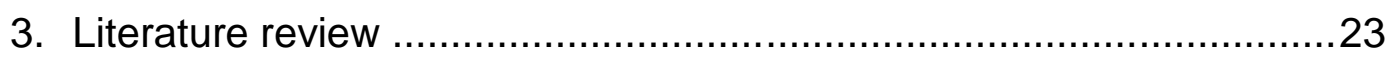

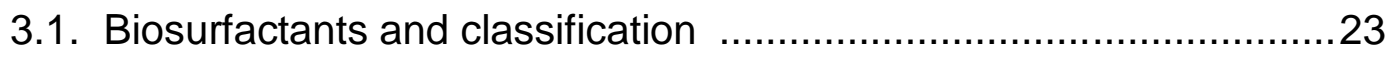

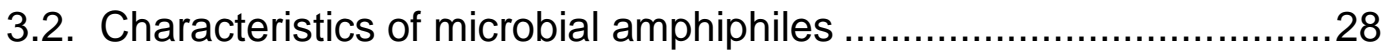

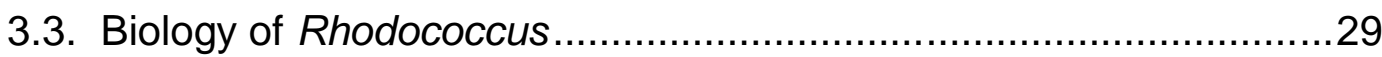

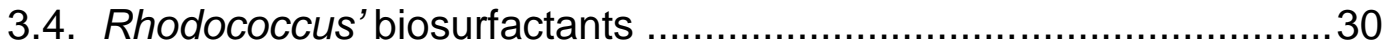

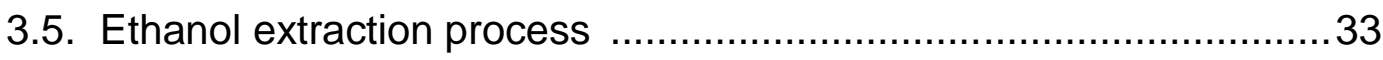

3.6. Electric double layer modeling and thermodynamic approach .......35

3.7. Hematite flotation studies using synthetic surfactants ..................... 40

3.8. Mineral flotation studies using R hodococcus opacus ......................41

3.9. Mineral flotation studies using biosurfactants ................................ 45

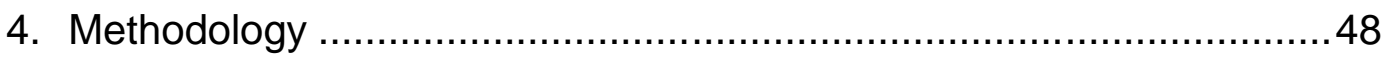

4.1. Microorganism and culture media ............................................. 48

4.2. Crude biosurfactant extraction and characterization by FTIR ...........48

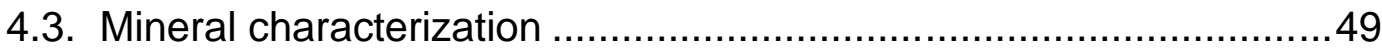

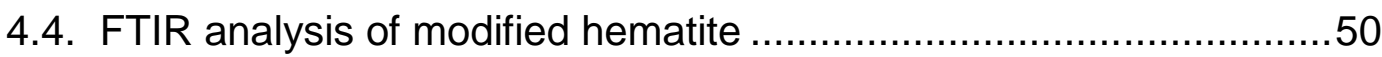

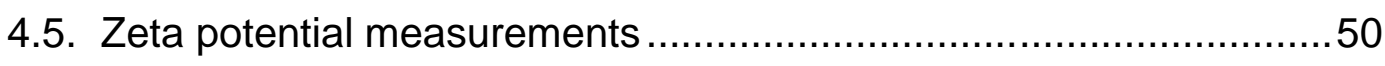

4.6. Surface tension measurements ....................................................

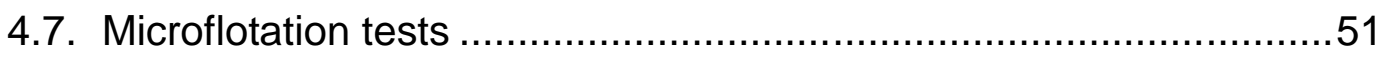

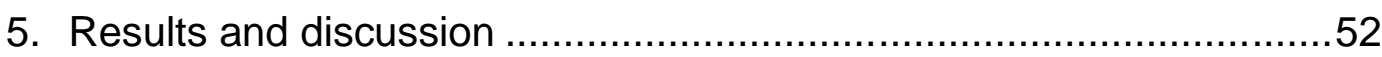

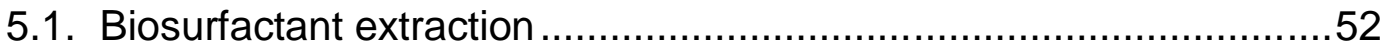


5.2. FTIR characterization of the R hodococcus opacus

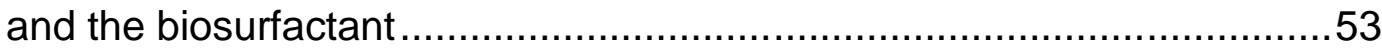

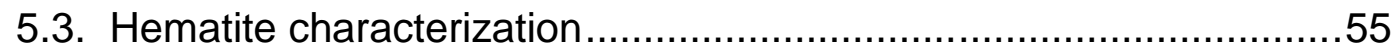

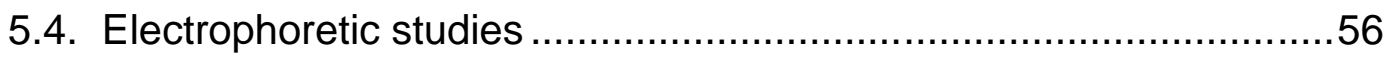

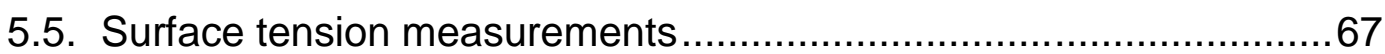

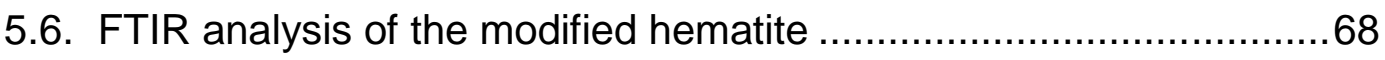

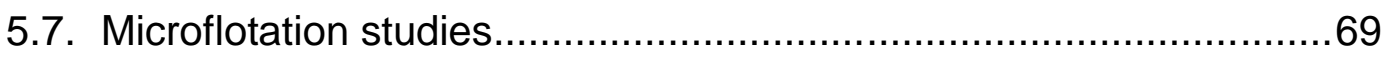

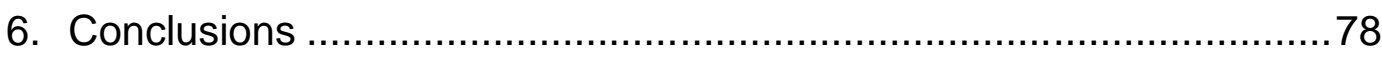

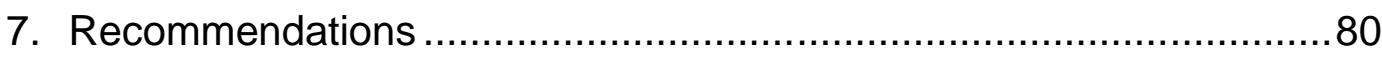

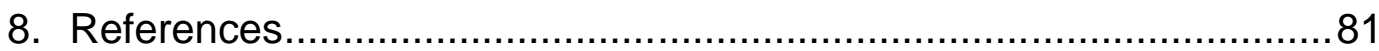

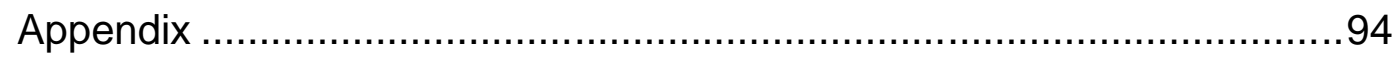




\section{List of figures}

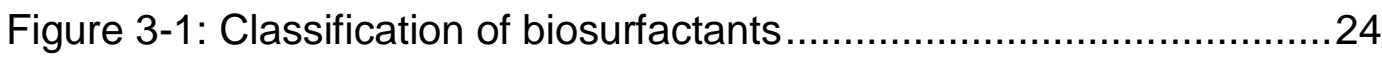

Figure 3-2: Chemical structure of a generic trehalolipid .........................26

Figure 3-3: Organization of the rhodococcal cell envelope.......................30

Figure 3-4: Biosurfactant isolation techniques.......................................32

Figure 3-5: Extraction curve showing cumulative concentrations

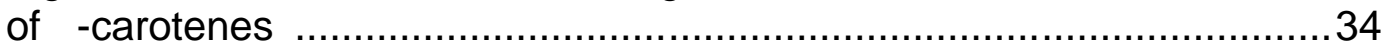

Figure 3-6: Influence of ethanol concentration on the acquired ratio of lignans

Figure 3-7: Helmholtz and Gouy-Chapman model of the electric

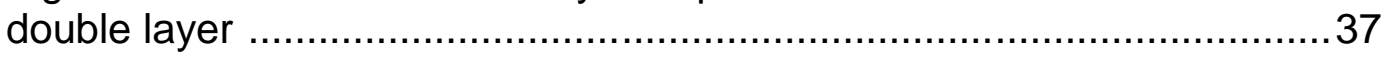

Figure 3-8: Stern layer at a metal surface ............................................38

Figure 3-9: Breaks at the Stern layer................................................ 39

Figure 3-10: Floatability of hematite as a function of SDS, sodium oleate and $\mathrm{C} 12$

Figure 3-11: Surface tension of R. opacus as function of the biomass concentration and $\mathrm{pH}$

Figure 3-12: Speciation of amino and carboxylic groups as a function of $\mathrm{pH}$

Figure 3-13: Zeta potential of $R$. opacus cells, quartz and hematite as a function of $\mathrm{pH}$.

Figure 3-14: Floatability of hematite (a) and quartz (b) as function of R. opacus cells' concentration and $\mathrm{pH}$.

Figure 3-15: Magnesite and serpentenite bioflotation as a function of biosurfactant concentration.

Figure 3-16: Hematite flotation with broth $(A)$ and pure biosurfactant (B)

Figure 4-1: Fluxogram of the hot ethanol extraction protocol.

Figure 5-1: FTIR spectra of the crude biosurfactant (above) and R hodococcus opacus.

Figure 5-2: FTIR spectra of hematite .56

Figure 5-3: Zeta potential of hematite particles in function of the $\mathrm{pH}$. 
Figure 5-4: Potential distribution applying the diffuse layer model. 60

Figure 5-5: Potential distribution of a spherical particle.

Figure 5-6: Electrostatic potential map as function of the distance and $\mathrm{pH}$......

Figure 5-7: Zeta potential of hematite particles before and after interaction with the crude biosurfactant

Figure 5-8: Estimated charge density of hematite particles as function of the $\mathrm{pH}$

Figure 5-9: Potential distribution before and after crude BS adsorption, applying the mixed model 66

Figure 5-10: Gibbs free energy variation of the electric double layer in function of the $\mathrm{pH}$

Figure 5-11: Effect of the crude biosurfactant concentration on the surface tension of water

Figure 5-12: FTIR spectra of hematite particles before and after interaction with the crude biosurfactant.....

Figure 5-13: Hematite floatability in function of $\mathrm{pH}$ and biomass concentration.

Figure 5-14: Proposed adhesion mechanism of $R$ hodococcus opacus with the mineral

Figure 5-15: Variability of hematite floatability in function of the $\mathrm{pH}$ and biomass concentration

Figure 5-16: Surface response $(A)$ and contour plot $(B)$ of hematite floatability with the biomass

Figure 5-17: Hematite floatability in function of the $\mathrm{pH}$ and $\mathrm{BS}$ concentration....

Figure 5-18: Variability of hematite floatability in function of the $\mathrm{pH}$ and crude biosurfactant concentration.

Figure 5-19: Surface response (A) and contour plot (B) of hematite floatability with the biosurfactant.

Figure 5-20: Bar diagram comparing hematite floatability using the crude biosurfactant (green) and the Rhodococcus opacus 


\section{List of photos}

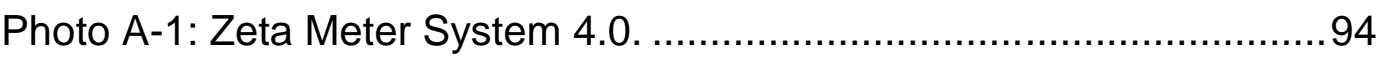

Photo A-2: Crude biosurfactant after the drying stage.............................94

Photo A-3: R hodococcus opacus in solid media. ...................................95

Photo A-4: Crude biosurfactant concentrate, 6500 ppm..........................95

Photo A-5: Biosurfactant froth with hematite particles .............................96

Photo A-6: R hodococcus opacus froth with hematite particles .................96 


\section{List of tables}

Table 3-1: Maximum hematite recoveries using C6-C18 saturated fatty acids

Table 3-2: Isoelectric point of $\mathrm{R}$. opacus determined in several studies

Table 4-1: Experimental plan for the electrophoretic studies.

Table 4-2: Multistage factorial design for the floatability tests.

Table 5-1: Possible functional groups identified by the FTIR spectra of R hodococcus opacus

Table 5-2: Possible functional groups identified by the FTIR spectra of the crude biosurfactant

Table 5-3: Fluorescence spectroscopy of hematite 55

Table 5-4: Hematite sample EDS 56

Table 5-5: Debye length of hematite particles.

Table 5-6: Coefficients of the polynomial regression with Rhodococcus opacus as reagent.

Table 5-7: Coefficients of the polynomial regression with crude biosurfactant as reagent.

Table B-1: Zeta potential measurements of hematite before and after interaction with the biosurfactant.

Table B-2: Estimated surface potential, based

on the Nerst equation.

Table B-3: Potential distribution in $\mathrm{mV}$, applying the simplified Poison-Boltzman equation for $\mathrm{pH} 3$.

Table B-4: Potential distribution in $\mathrm{mV}$, applying the simplified Poison-Boltzman equation for $\mathrm{pH} 5$.

Table B-5: Potential distribution in $\mathrm{mV}$, applying the simplified Poison-Boltzman equation for $\mathrm{pH} 7$.

Table B-6: Potential distribution in $\mathrm{mV}$, applying the simplified Poison-Boltzman equation for $\mathrm{pH} 9$.

Table B-7: Estimated charge density as function of the $\mathrm{pH}$. 
Table B-8: Estimated shear plane distance as function of the $\mathrm{pH}$ before and after biosurfactant interaction.

Table B-9: Potential distribution applying the plate capacitor and the Gouy-Chapman model

Table B-10: Hematite recovery in function of $\mathrm{pH}$ and Rhodococcus opacus concentration.

Table B-11: Hematite recovery in function of $\mathrm{pH}$ and biosurfactant concentration. 


\section{List of symbols}

Latin characters:

BS Biosurfactant

CMC Critical micelle concentration

$c_{z p} \quad$ Ion concentration at the point of zero charge, $\mathrm{mol} \mathrm{dm} \mathrm{dm}^{-3}$

$c_{0} \quad$ Initial ion concentration, mol $\mathrm{dm}^{-3}$

$F \quad$ Faraday constant, $96485.3 \mathrm{~s} \mathrm{~A} \mathrm{~mol}^{-1}$

IEP Isoelectric point

$k_{B} \quad$ Boltzman constant, 1.38E-23 $\mathrm{m}^{2} \mathrm{~kg} \mathrm{~s}^{-2} \mathrm{~K}^{-1}$

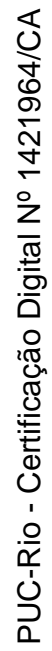

PZC Point of zero charge

$R \quad$ Universal gas constant, $8.314 \mathrm{~J} \mathrm{~K}^{-1} \mathrm{~mol}^{-1}$

$T$ Absolute temperature, $\mathrm{K}$

$x \quad$ Distance from the particle surface, $\mathrm{m}$

\section{Greek characters:}

$\Delta G \quad$ Free energy Gibbs variation, $\mathrm{J} \mathrm{m}^{-2}$

$\lambda_{D} \quad$ Debye length, $\mathrm{m}$

$\Psi_{0} \quad$ Surface potential, $\mathrm{mV}$

$\varepsilon_{0} \quad$ Vacuum permittivity

$\varepsilon_{\text {r }} \quad$ Dielectric constant of water

$\delta$ Distance between the opposite charges

$\sigma \quad$ Charge density per area, $\mathrm{C} \mathrm{m}^{-2}$

$\rho_{e} \quad$ Charge density per volume, $\mathrm{C} \mathrm{m}^{-3}$ 


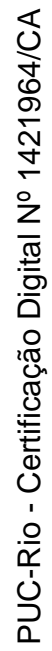

"People don't choose dreams, dreams choose you" I.W. 